\title{
Analisis Portofolio Optimum Saham Syariah Dengan Model Black Litterman
}

\author{
Arum Virgina Dewi Kusuma Ratri \\ Program Studi Matematika Fakultas Sains dan Teknologi, UIN Sunan Kalijaga, Jl. Marsda Adisucipto \\ No. 1 Yogyakarta, Indonesia \\ Korespondensi; Email: virginadhe@gmail.com
}

\begin{abstract}
Abstrak
Kegiatan berinvestasi yang dilakukan oleh investor tidak dapat terlepas dari faktor return dan risiko. Pembentuk portofolio menjadi suatu pilihan yang dapat membantu meminimalkan risiko dan mengoptimalkan keuntungan. Salah satunya adalah model portofolio Black Litterman (BL). Model ini merupakan model yang mengkombinasikan antara return ekuilibrium yang diperoleh melalui Capital Asset Pricing Model (CAPM) dengan pandangan/views investor tentang return suatu aset. Penelitian ini membahas tentang penerapan model Black Litterman pada saham syariah yang tergabung dalam Jakarta Islamic Index (JII) periode Januari 2014 - Januari 2015. Pemilihan portofolio dilakukan dengan memilih 5 (lima) saham yang memiliki expected return CAPM terbesar diperoleh saham INDF, MNCN, MPPA, SILO dan SSMS. Hasil penelitian menunjukkan bahwa portofolio model Black Litterman terbentuk dari saham INDF $(54,44 \%)$, MNCN $(11,69 \%)$, MPPA $(13,17 \%)$ dan SSMS $(20,70 \%)$ dengan return $0,13 \%$ dan risiko $0,0114 \%$.
\end{abstract}

Kata Kunci: CAPM; Model Black Litterman; Saham Syariah; Portofolio O ptimum

\begin{abstract}
Investing activities undertaken by investors can not be separated from the return and risk factors. Molders the portfolio becomes an option that can help minimize risk and optimize profitability. One is a model portfolio Black Litterman (BL). This model is a model that combines the equilibrium returns obtained through the Capital Asset Pricing Model (CAPM) to view / views of investors about the return of an asset. This study discusses the application of the Black Litterman on Islamic stocks incorporated in the Jakarta Islamic Index (JII) in the period January 2014 - January 2015. The selection is done by selecting a portfolio of five (5) shares had the biggest CAPM expected return acquired shares INDF, MNCN, MPPA, SILO and SSMS. The results showed that Black Litterman model portfolio made up of shares INDF $(54.44 \%)$, MNCN $(\mathbf{1 1 . 6 9 \%})$, MPPA $(13.17 \%)$ and SSMS $(20.70 \%)$ with a return of $0.13 \%$ and a risk $0.0114 \%$.
\end{abstract}

Keywords: CAPM ; Black Litterman Model; Islamic stocks; O ptimum Portfolio

\section{Pendahuluan}

Investasi sering diartikan komitmen untuk mengalokasikan sejumlah dana pada atau lebih asset (pada saat ini) yang diharapkan akan mampu memberikan return (keuntungan) dimasa yang akan datang. Kegiatan investasi yang dilakukan investor akan menghasilkan keuntungan (return) dan sekaligus menghadapi risiko (risk). Keuntungan dan risiko berbanding lurus, apabila keuntungan tinggi berarti risikonya juga tinggi dan sebaliknya, apabila keuntungannya rendah risikonya juga akan rendah. Hukum investasi ini berlaku untuk semua jenis investasi. Permasalahannya adalah bahwa setiap orang menginginkan keuntungan yang tinggi dengan risiko yang rendah (Susilo, 2009: 3).

Strategi yang sering digunakan dalam kondisi investasi yang penuh dengan risiko adalah dengan membentuk portofolio (portfolio). Portofolio adalah kombinasi dari beberapa saham sebagai pilihan investasi. Tujuannya untuk meminimalkan risiko investasi dan mengoptimalkan keuntungan atau diversifikasi investasi (Susilo, 2009:150). 
Menurut Jogiyanto (2000:169) dalam membentuk suatu portofolio dipastikan akan timbul suatu masalah. Permasalahannya adalah terdapat banyak sekali kemungkinan portofolio yang dapat dibentuk dari kombinasi aktiva berisiko yang tersedia di pasar. Kombinasi ini dapat mencapai jumlah yang tidak terbatas. Belum kombinasi ini juga memasukkan aktiva bebas risiko di dalam pembentukan portofolio. Jika terdapat kemungkinan portofolio yang jumlahnya tidak terbatas, maka akan timbul pertanyaan portofolio mana yang akan dipilih oleh investor. Jika investor adalah rasional, maka mereka akan memilih portofolio yang optimal.

Teori portofolio diawali oleh Markowitz dengan mean variance efficient portfolio di tahun 1952. Selanjutnya bermunculan teori tentang portofolio seperti CAPM dan Single Index Model. Hingga pada tahun 1992 muncul model portofolio yang dikenal dengan Black Litterman Model (BL) oleh Robert Litterman dan Fischer Black. BL muncul dengan rumusan yang tidak mengabaikan views" seorang investor atau manajer investasi. Seorang investor tentunya memiliki views tersendiri terhadap suatu aset yang akan dipilihnya untuk melakukan investasi. Sehingga tidak seperti kebanyakan model portofolio yang hanya menggunakan data historis dan tidak mempedulikan pandangan investor, portofolio yang terbentuk dari model Black Litterman ini diharapkan akan lebih menguntungkan karena diperoleh dengan melalui data historis dan juga views yang telah dinyatakan oleh investor (Subekti, 2009:1).

Black dan Litterman mengidentifikasi dua sumber informasi tentang expected return dan mengkombinasikan dua informasi itu ke dalam rumus expected return yang baru. Informasi yang pertama diperoleh dari return CAPM sehingga market dianggap dalam keadaan ekuilibrium. Sumber informasi yang kedua adalah views manajer investasi. Manajer investasi dapat menyatakan opininya yang berbeda dengan kondisi ekuilibrium, informasi yang berbeda ini mungkin sekali karena berkaitan dengan expected return asset apakah akan meningkat atau turun berdasarkan pantauan investor terhadap keadaan market, perekonomian ataupun isu-isu politik dan kenegaraan yang mungkin mempengaruhi pergerakan aset di market. Views investor dengan return ekuilibrium akan menghasilkan informasi untuk mendapatkan expected return yang baru yang akan digunakan untuk proses optimisasi portofolio (Subekti, 2009: 4).

Model Black Litterman ini dapat ditelusuri dari berbagai pendekatan, yaitu Bayes, Teori Sampling dan Theil Mixed. Menurut Silva (2009:2) model Black Litterman dengan kerangka analisis Bayes dapat menghasilkan portofolio yang lebih kuat, yang mana memiliki sensitifitas kecil pada error yang masuk pada expected return. Oleh karena itu, penelitian ini melakukan analisis portofolio optimum saham syariah yang tergabung dalam Jakarta Islamic Index (JII) dengan Model Black Litterman Periode Januari 2014 Januari 2015 menggunakan pendekatan Bayes.

\section{Landasan Teori}

\section{Pasar Modal Syariah}

Berdasarkan Peraturan Nomor IX.A.13 tentang penerbitan Efek Syariah, Efek Syariah adalah Efek sebagaimana dimaksud dalam Undang-undang Pasar Modal dan peraturan pelaksanaannya yang akad maupun cara penerbitannya memenuhi Prinsip-prinsip Syariah di Pasar Modal (Suhartono, 2009: 203).

Seperti pasar modal pada umumnya, pasar modal syariah memberikan sarana investasi dengan berbagai tawaran produk yang dapat dipilih oleh masyarakat sebagai investor seperti saham, obligasi (sukuk) dan reksadana syariah. Secara rinci dapat dijelaskan sebagai berikut (Suhartono, 2009: 207):

\section{a. Saham dan Portofolio}

Suatu perusahaan dapat menjual hak kepemilikannya dalam bentuk saham (stock). Saham merupakan sertifikat yang menunjukkan atas suatu perusahaan yang menurut proporsi tertentu. Jika perusahaan hanya mengeluarkan satu kelas saham saja, saham ini disebut saham biasa (common stock). Untuk menarik investor potensial lainnya, suatu perusahaan mungkin juga mengeluarkan kelas lain dari saham, yaitu yang disebut saham preferen (preferred stock) (Jogiyanto, 2000: 67).

Dari sudut pandang figh, pada dasarnya saham adalah efek syariah. Namun saham dapat menjadi tidak syariah apabila perusahaan yang menerbitkan (emiten) tidak memenuhi kriteria syariah yang ditetapkan oleh Dewan Syariah Nasional-Majelis Ulama Indonesia (DSN-MUI) yang 
telah diatur dalam peraturan Bapepam-LK nomor II K.1 tentang Kriteria dan Penerbitan Daftar Efek Syariah (Suhartono, 2009: 207).

Sedangkan portofolio merupakan kumpulan instrumen investasi yang dibentuk untuk memenuhi suatu sasaran umum investasi yaitu mengurangi risiko (Suhartono, 2009: 119).

b. Sukuk (Obligasi Syariah)

Sukuk atau yang dulunya lebih dikenal dengan Obligasi Syariah merupakan Efek Syariah berupa sertifikat atau bukti kepemilikan yang bernilai sama dan mewakili bagian penyertaan yang terbagi atas (Suhartono, 2009: 209):

1) Kepemilikan asset berwujud tertentu

2) Nilai manfaat dan jasa atas asset proyek tertentu atau aktivitas investasi tertentu, atau

3) Kepemilikan atas asset proyek tertentu atau aktivitas investasi tertentu.

c. Reksadana Syariah

Berdasarkan Fatwa Dewan Syariah Nasional-Majelis Ulama Indonesia (DSN-MUI) Nomor 20/DSNMUI/IV/2001 mengenai Pedoman Pelaksaan.

Investasi untuk Reksadana Syariah dan Nomor 40/DSN-MUI/X/2003 mengenai Pasar Modal, definisi reksadana syariah adalah reksadana yang beroperasi menurut ketentuan dan prinsip syariah Islam, baik dalam bentuk akad antara pemodal sebagai pemilik harta (shahib al-mal/rabb al-mal) dengan Manajer Investasi, begitu pula pengelolaan dana investasi sebagai wakil shahib al-mal, maupun antara Manager Investasi sebagai wakil shahib al-mal dengan pengguna investasi (Suhartono, 2009: 211).

\section{Teorema Bayes}

Teorema Bayes merupakan salah satu cara yang banyak digunakan untuk merevisi peluang awal (peluang prior) sehingga diperoleh peluang akhir (peluang posterior) yang selanjutnya dijadikan dasar untuk pengambilan keputusan. Konsep peluang ini dikemukakan oleh Thomas Bayes (1702-1761). Teorema bayes banyak digunakan terkait permasalahan peluang bersyarat. Peluang sebelum direvisi disebut peluang awal (prior probability) dan peluang yang diperbarui disebut peluang akhir (posterior probability) (Sugiarto, 2014: 8.10).

Misal peristiwa-peristiwa $B_{1}, B_{2}, \ldots, B_{k}$ membentuk partisi di dalam ruang sampel $\mathrm{S}$ demikian sehingga $P\left(B_{i}\right) \neq 0, i=1,2,3, \ldots, k$ dan misalkan pula $A$ suatu kejadian sembarang dalam $\mathrm{S}$ dengan $P(A) \neq 0$, maka (Walpole, 1992: 110) :

Untuk $r=1,2, . ., i$

$$
P\left(B_{r} \mid A\right)=\frac{P\left(B_{r}\right) P\left(A \mid B_{r}\right)}{\sum_{i=1}^{k} P\left(B_{i}\right) P\left(A \mid B_{i}\right)}
$$

\section{Return Saham dan Portofolio}

- Return Portofolio

Menurut Jogiyanto return portofolio terdapat dua macam, yaitu return realisasi portofolio dan return ekspektasi portofolio.

- Return Realisasi Portofolio

Return realisasi portofolio adalah rata-rata tertimbang dari return-return realisasi masing-masing sekuritas tunggal dalam portofolio, yaitu (Jogiyanto, 2000: 142):

Dengan:

$$
\begin{aligned}
R_{p} & =W_{1} R_{1}+\cdots+W_{K} R_{K} \\
& =\sum_{i=1}^{n} W_{i} R_{i}
\end{aligned}
$$

$w_{i}=$ bobot aset-aset dalam portofolio

$R_{i}=$ return saham ke-i.

dimana $w$ jika dijumlahkan akan memiliki jumlah sama dengan 1. 
- Return Ekspektasi Portofolio

Return ekspektasi portofolio merupakan rata-rata tertimbang return-return ekspektasi untuk tiap-tiap sekuritas tunggal di dalam portofolio, yaitu (Jogiyanto, 2000:142):

$$
\begin{aligned}
R_{p} & =w_{i} r_{i}+\cdots+w_{n} r_{n} \\
E\left(R_{p}\right) & =w_{i} E\left(R_{i}\right)+\cdots+w_{n} E\left(R_{n}\right) \\
& =\sum_{i=1}^{n} w_{i} E\left(R_{i}\right)
\end{aligned}
$$

- Risiko Saham dan Portofolio

Risiko merupakan besarnya penyimpangan antara tingkat pengembalian yang diharapkan (expected return) dengan tingkat pengembalian aktual. Semakin besar penyimpangannya berarti semakin besar pula tingkat risikonya (Halim, 2003: 42).

- Risiko Saham

Risiko saham adalah risiko atau penyimpangan yang diperoleh dari suatu saham tertentu. Risiko saham dapat dihitung dengan rumus berikut (Jogiyanto, 2000: 131):

$$
V \quad\left(R_{i}\right)=E\left(\left[R_{i}-E\left(R_{i}\right)\right]^{2}\right)
$$

- Risiko Portofolio

Risiko suatu portofolio dinotasikan (Jogiyanto, 2000: 155):

dimana:

$$
\begin{aligned}
V \quad\left(R_{p}\right) & =V \quad\left(w^{\prime} r\right) \\
& =w^{\prime} V \quad(r) w \\
& =w^{\prime} \sum w
\end{aligned}
$$

$R_{p}=$ return realisasi portofolio

$r=$ mean return aset portofolio

$w=$ bobot aset-aset dalam portofolio

\section{Beta}

Besarnya risiko suatu saham ditentukan oleh beta $(\beta)$ Beta menunjukkan hubungan antara saham dan pasarnya (saham secara keseluruhan). Beta juga merupakan pengukur volatilitas return suatu sekuritas atau portofolio terhadap return pasar.

$$
\beta_{i}=\frac{\sigma_{i}}{\sigma_{M}^{2}}
$$

dengan:

$\sigma_{i i}=$ covarian return dari masing-masing saham dengan return pasar

$\sigma_{M}^{2}=$ varian return pasar

\section{Teori CAPM}

CAPM (Capital Asset Pricing Model) merupakan suatu model yang menggunakan beta untuk menghubungkan risiko dan return secara bersama-sama. Pengembangan model ini berfungsi untuk menjelaskan tingkah laku dari harga-harga sekuritas dan memberikan mekanisme bagi investor untuk menilai pengaruh suatu sekuritas yang diusulkan terhadap risiko dan return portofolio mereka. Teori CAPM ini dikembangkan oleh William Sharpe (1964), John Lintner (1965), Jan Mossin (1966) dan Jack Treynor (1961), yang mengembangkan mean-variance analysis dari Markowitz menjadi model yang dapat menghitung expected return asset jika ekuilibrium tercipta dalam pasar (Suhartono, 2009: 89).

Formula CAPM. CAPM (Capital Asset Pricing Model) merupakan suatu model yang menggunakan beta untuk menghubungkan risiko dan return secara bersama-sama. 
Rumusan CAPM (Sigman, 2005: 2):

$$
\bar{r}_{p}-r_{f}=\beta_{p}\left(\bar{r}_{M}-r_{f}\right)
$$

\section{Diversifikasi}

Diversifikasi merupakan risiko yang dapat di-diversifikasikan adalah risiko yang tidak sistematik atau risiko spesifik. Diversifikasi risiko ini sangat penting untuk investor, karena dapat meminimumkan risiko tanpa harus mengurangi return yang diterima (Jogiyanto, 2000: 162).

- Diversifikasi Random

Diversifikasi secara random (nave diversification) merupakan pembentukan dengan memilih sekuritassekuritas secara acak tanpa memperhatikan karakteristik dari investasi yang relevan seperti misalnya return dari sekuritas itu sendiri. Investor hanya memilih sekuritas secara acak.

- Diversifikasi Markowitz

Sebelumnya telah ditunjukkan dengan menggunakan metode dari Markowitz, sekuritas-sekuritas yang mempunyai korelasi lebih kecil dari 1 akan menurunkan risiko portofolio. Dengan kata lain, saat melakukan diversifikasi, dianjurkan menghidari saham-saham yang berkorelasi positif, atau pilihlah saham yang berkorelasi negatif. Semakin banyak sekuritas yang dimasukkan dalam portofolio, semakin kecil risiko portofolio. Dengan menggunakan metode Markowitz, diversifikasi ini dapat dibuktikan secara matematis.

Misalkan terdapat $\mathrm{n}$ sekuritas dalam portofolio dengan proporsi $w_{i}$. Besar $w_{i}$ adalah $1 / \mathrm{n}$ (misal $\mathrm{n}$ adalah 4 , maka proporsi tiap sekuritas atau $25 \%$ ). Ingat rumus varian portofolio sebagai berikut:

$$
\sigma_{p}^{2}=\sum_{i=1}^{n} \sum_{j=1}^{n} w_{i} w_{j} \sigma_{i}
$$

Subtitusikan $w_{i}=w_{j}=1 / n$, maka besar varian portofolio adalah

$$
\begin{aligned}
\sigma_{p}^{2} & =\sum_{i=1}^{n} \sum_{j=1}^{n} \frac{1}{n} \frac{1}{n} \sigma_{i} \\
& =\frac{1}{n^{2}} \sum_{i=1}^{n} \sum_{j=1}^{n} \sigma_{i}
\end{aligned}
$$

Pecah kembali (2-59) menjadi varian dan kovarian:

$$
\sigma_{p}^{2}=\frac{1}{n^{2}} \sum_{i=1}^{n} \sigma_{i i}+\frac{1}{n^{2}} \sum_{i=1}^{n} \sum_{j=1}^{n} \sigma_{i}
$$

Misalkan varian terbesar untuk tiap-tiap aktiva $\left(\sigma_{i 1}\right)$ adalah $\mathrm{T}$, maka rumus varian portofolio menjadi:

$$
\begin{aligned}
\sigma_{p}^{2} & =\frac{1}{n^{2}} \sum_{i=1}^{n} T+\frac{1}{n^{2}} \sum_{i=1}^{n} \sum_{j=1}^{n} \sigma_{i} \\
& =\frac{1}{n^{2}} T \cdot n+\frac{1}{n^{2}} \sum_{i=1}^{n} \sum_{j=1}^{n} \sigma_{i} \\
& =\frac{T}{n}+\frac{1}{n^{2}} \sum_{i=1}^{n} \sum_{j=1}^{n} \sigma_{i}
\end{aligned}
$$

Misalkan nilai rata-rata dari kovarian adalah $\bar{\sigma}_{i}$ dan jumlah dari kovarian adalah $\left(n^{2}-n\right)$ buah, maka total nilai semua kovarian adalah sebesar $\left(n^{2}-n\right) \cdot \bar{\sigma}_{i}$. Subtitusikan nilai ini ke rumus varian portofolio, sehingga menjadi: 


$$
\begin{aligned}
\sigma_{p}^{2} & =\frac{T}{n}+\frac{1}{n^{2}}\left[\left(n^{2}-n\right) \cdot \bar{\sigma}_{i}\right] \\
& =\frac{T}{n}+\left(\frac{n^{2}}{n^{2}} \cdot \bar{\sigma}_{i}-\frac{n}{n^{2}} \cdot \bar{\sigma}_{i}\right) \\
& =\frac{T}{n}+\left(\bar{\sigma}_{i}-\frac{1}{n} \cdot \bar{\sigma}_{i}\right)
\end{aligned}
$$

Diversifikasi dapat ditunjukkan dengan jumlah aktiva yang besar dalam portofolio sebagai berikut:

$$
\lim _{n \rightarrow \infty} \sigma_{p}^{2}=\lim _{n \rightarrow \infty}\left[\frac{T}{n}+\left(\bar{\sigma}_{i i}-\frac{1}{n} \cdot \bar{\sigma}_{i i}\right)\right]
$$

Sehingga, risiko dari portofolio adalah

$$
\lim _{n \rightarrow \infty} \sigma_{p}^{2}=\bar{\sigma}_{i i}
$$

Dengan demikian, diversifikasi akan menghilangkan efek varian, tetapi efek kovarian masih tetap ada, yaitu sebesar nilai rata-rata semua kovarian. Dengan kata lain, untuk portofolio yang didiversifikasikan dengan baik yang terdiri dari banyak aktiva, efek dari kovarian menjadi lebih penting dibandingkan efek dari varian masing-masing aktiva (Jogiyanto, 2000: 164-167).

\section{Model Black Litterman}

\section{Pengertian Model Black Litterman}

Model Black Litterman dengan menggunakan pendekatan bayes digunakan untuk mengkombinasikan views subjektif dari pandangan investor tentang expected return satu aset atau lebih dengan vektor ekuilibrium pasar dari expected return (distribusi prior), ke bentuk yang baru. Estimasi campuran dari expected return, vektor yang baru dari return (distribusi posterior) dan kepastian intuisi portofolio sehingga terbentuk bobot portofolio yang tepat (Idzorek, 2005).

Pendekatan ini merupakan salah satu cara yang digunakan mengungkapkan perbedaan yang sangat mencolok tentang expected return ketika dibandingkan dengan kesepakatan pasar.

\section{Views Investor dan Tingkat Keyakinan Investor}

- Views Investor

Seorang investor dapat memiliki pandangan hanya untuk sejumlah $\mathrm{k}$ aset dari $\mathrm{d}$ aset yang terdapat dalam portofolio, dengan kata lain investor tidak perlu menyatakan pandangannya (view) pada tiaptiap aset pada semua portofolio namun cukup pada sejumlah portofolio yang menjadi perhatian investor.

Misalkan suatu portofolio terdiri dari 3 aset yaitu A, B dan C. Investor dapat menyatakan view, baik relative view ataupun absolute view, yaitu:

View 1 (absolute view): saya yakin aset $\mathrm{A}$ akan memberikan return $\mathrm{X} \%$

View 2 (relative view): saya yakin aset B akan memberikan return $\mathrm{Y} \%$ melampaui aset $\mathrm{C}$

Sehingga dapat dibentuk $Q$ sebagai view vector.

$$
Q+\varepsilon=\left[\begin{array}{c}
Q_{1} \\
\vdots \\
Q_{K}
\end{array}\right]+\left[\begin{array}{c}
\varepsilon_{1} \\
\vdots \\
\varepsilon_{K}
\end{array}\right]
$$

Variansi dari masing-masing error dinyatakan ke dalam matriks baru. Diagonal dalam matriks menunjukkan covarian antar views. Matriks akan berkontribusi penting dalam perhitungan akhir expected return Black Litterman.

Sebelum menuju ke perhitungan akhir expected return, terlebih dahulu dibahas tentang matriks koefisien $P$ (Idzorek, 2005): 


$$
P=\left[\begin{array}{ccc}
p_{1,1} & \cdots & p_{1, n} \\
\vdots & \ddots & \vdots \\
p_{k, 1} & \cdots & p_{k, n}
\end{array}\right]
$$

$P$ adalah matriks $k x n$, dimana $k$ menunjukkan views investor dan $n$ menunjukkan banyaknya aset dalam portofolio.

- Tingkat Keyakinan Investor

Model Black Litterman yang diawali dengan equilibrium return yang dicapai CAPM, mempersilahkan investor untuk menggabungkan sejumlah aset dengan investmen views. Ketidakpastian views dapat diukur dari (tingkat keyakinan) confidence level tertentu. Confidence level terletak pada interval $0 \%$ sampai $100 \%$.

Tingkat keyakinan merupakan vektor error yang menandakan pandangan yang dimiliki investor masih belum pasti dan diasumsikan berdistribusi normal. Tingkat keyakinan ini dinyatakan dalam matriks diagonal $\Omega$ (kovariansi dari views) sebagai berikut (Idzorek, 2005):

$$
\Omega=P^{\prime} \alpha \sum P
$$

Dimana $\alpha=\frac{1-c}{c}$

dengan bentuk matriksnya

$$
\Omega=\left[\begin{array}{ccc}
\left(p_{k} \sum p_{k}^{\prime}\right) * \alpha & 0 & 0 \\
0 & \ddots & 0 \\
0 & 0 & \left(p_{k} \sum{p^{\prime}}_{k}\right) * \alpha
\end{array}\right]
$$

\section{Asumsi Model}

Dalam teorema bayes, probabilitas $P(A)$ menggambarkan tentang informasi prior. Informasi prior ini didapatkan dari informasi $B$.

Misalkan:

$A=$ expected return

$B=$ equilibrium return

$$
P(A \mid B)=P(A \mid B) P(B)=P(B \mid A) P(A)
$$

Sehingga

$$
P(A \mid B)=\frac{P(A)}{P(B)}=\frac{P(B \mid A) P(A)}{P(B)}
$$

Keterangan:

$P(A \mid B)=$ fungsi probabilitas expected return jika diketahui data equilibrium return, disebut juga distribusi prior

$P(A) \quad=$ pandangan subjektif investor

$P(B) \quad=$ probabilitas marginal ekuilibrium

Kemudian dengan aturan bayes maka informasi $A$ dan $B$ dapat dibawa ke bentuk

dengan

$$
P(E(r) \mid \pi)=\frac{P(\pi \mid E(r)) P(E(r))}{P(\pi)}
$$

$r=$ vektor excess return ukuran $\mathrm{n} \times 1 ; E(r)=$ vektor expected return investor ukuran $\mathrm{n} \times 1 ; \pi=$ excess equilibrium CAPM 
Dengan asumsi-asumsi sebagai berikut (Subekti, 2008):

Asumsi Pertama: Diasumsikan keyakinan prior dinyatakan sebagai $P(E(r))$ yang mempunyai $k$ kendala linear dari vektor expected return dan ditulis dengan matriks $P$ dengan ukuran $k \times n$

$$
P(r)=Q+v
$$

dengan $v \sim N(0, \Omega), \Omega$ adalah matriks kovariansi $\mathrm{k} \times \mathrm{k}$, sehingga distribusinya

$$
P(r) \sim N(Q, \Omega)
$$

Asumsi Kedua: Fungsi densitas dari data equilibrium return dengan syarat informasi prior diasumsikan sebagai

$$
\pi \mid E(r) \sim N(E(r), \Sigma)
$$

Dengan $E(\pi)=E(r)$ artinya ada asumsi bahwa mean return ekuilibrium sama dengan mean return pasar, ini diperoleh melalui CAPM. Sedangkan scalar $\tau$ adalah suatu angka yang diberikan investor untuk mengukur matriks kovariansi historis $\Sigma$. Variabel $\tau=1 / j u \quad h o$ (Blamont dan Firoozye, 2003).

\section{Kombinasi Equilibrium Return dan Views Investor}

Informasi prior yang dimiliki investor tidaklah pasti sehingga matriks kovariansinya bukanlah nol, dengan menggunakan asumsi (21) dan (22) serta aturan bayes diperoleh fungsi densitas posterior $(E(r) \mid \pi)$ adalah multivariat normal dengan mean dan variansinya sebagai berikut (Subekti, 2008): Mean posterior

$$
\left[(\tau \Sigma)^{-1}+P^{\prime} \Omega^{-1} P\right]^{-1}\left[(\tau \Sigma)^{-1} \pi+P^{\prime} \Omega^{-1} Q\right]
$$

Variansi

$$
\left[(\tau \Sigma)^{-1}+P^{\prime} \Omega^{-1} P\right]^{-1}
$$

Mean adalah

$$
S^{-1} T=\left[(\tau \Sigma)^{-1}+P^{\prime} \Omega^{-1} P\right]^{-1}\left[(\tau \Sigma)^{-1} \pi+P^{\prime} \Omega^{-1} Q\right]
$$

Variansinya adalah

$$
S^{-1} T=\left[(\tau \Sigma)^{-1}+P^{\prime} \Omega^{-1} P\right]^{-1}
$$

Jadi $(E(r) \mid \pi)$ atau distribusi return kombinasi yang baru sebagai distribusi posterior berdistribusi multivariat normal.

Selanjutnya

$$
\mu_{b}=\pi+\left(\tau \Sigma P^{\prime}\right)\left(\Omega+P^{\prime} \tau \Sigma P\right)^{-1}(Q-P)
$$

\section{Dengan}

$$
\begin{aligned}
& \mu_{b}=\text { expected return Model Black Litterman } \\
& \pi=\text { return ekuilibrium } \\
& \tau=\text { parameter yang ditentukan investor (1/Pengamatan) } \\
& \Sigma \quad=\text { variansi kovariansi return } \\
& \Omega=\text { matriks diagonal kovariansi dari views ukuran kxk } \\
& P \quad=\text { matriks diagonal kovariansi dari views ukuran kxn } \\
& Q=\text { vector views return ukuran } \mathrm{kx} 1
\end{aligned}
$$


Pembobotan dengan Markowitz

$$
W_{b}=W_{m}+P^{\prime}\left(\frac{\Omega}{\tau}+P^{\prime} \Sigma P\right)^{-1}\left(\frac{Q}{\delta}-P \Sigma W_{m}\right)
$$

Dengan

$W_{b}=$ bobot aset menurut Model Black Litterman

$\delta \quad=$ risk averse

$W_{m}=$ bobot aset menurut return ekuilibrium

Mean Return portofolio

$$
R_{b}=\sum_{i=1}^{n} W_{b} \mu_{b}
$$

dan risikonya

$$
\sigma_{b}^{2}=\left(W_{b}^{*}\right)^{T} \sum W_{b}
$$

\section{Hasil dan Pembahasan}

Sampel yang terpilih dari penerapan teknik pengambilan sampel di atas adalah 23 sampel saham syariah dari populasi yang berjumlah 30 saham syariah. Sampel ini akan menjadi dasar untuk perhitungan expected return CAPM atau return ekuilibrium. Return ekuilibrium tersebut akan menjadi

\begin{tabular}{|c|c|c|c|c|c|c|c|}
\hline No. & Kode & Mean Return & Varian & No. & Kode & Mean Return & Varian \\
\hline 1 & AKRA & 0,0003 & 0,0003 & 13 & MPPA & 0,0024 & 0,0006 \\
\hline 2 & ASII & 0,0005 & 0,0003 & 14 & PGAS & 0,0004 & 0,0002 \\
\hline 3 & ASRI & 0,0012 & 0,0006 & 15 & PTBA & 0,0004 & 0,0005 \\
\hline 4 & BSDE & 0,0016 & 0,0005 & 16 & РТРP & 0,0043 & 0,0005 \\
\hline 5 & CPIN & 0,0006 & 0,0004 & 17 & SILO & 0,0012 & 0,0004 \\
\hline 6 & ICBP & 0,0012 & 0,0003 & 18 & SMGR & 0,0001 & 0,0003 \\
\hline 7 & INCO & 0,0009 & 0,0006 & 19 & SMRA & 0,0027 & 0,0007 \\
\hline 8 & INDF & 0,0005 & 0,0002 & 20 & SSMS & 0,0025 & 0,0005 \\
\hline 9 & INTP & 0,0005 & 0,0004 & 21 & TLKM & 0,0010 & 0,0002 \\
\hline 10 & KLBF & 0,0014 & 0,0002 & 22 & UNVR & 0,0012 & 0,0002 \\
\hline 11 & LPKR & 0,0008 & 0,0005 & 23 & WIKA & 0,0031 & 0,0005 \\
\hline 12 & MNCN & 0,0003 & 0,0005 & & & & \\
\hline
\end{tabular}
awal penentuan expected return model Black Litterman.

Tabel 1 Analisis Deskriptif.

\section{Pembentukan Portofolio dengan CAPM}

Saham-saham syariah dengan mean return positif yang telah menjadi sampel dalam penelitian ini, selanjutnya akan digunakan dalam menghitung nilai expected return model CAPM. Model CAPM ini menggunakan beta untuk menghubungkan risiko dan return secara bersama-sama. Risiko masing-masing aset dinyatakan dengan besarnya covarian return dari masing-masing saham dengan return pasar $\left(\sigma_{i 1}\right)$. Sedangkan beta $(\beta)$ yang merupakan pengukur risiko dinyatakan dengan rumus $\left(\sigma_{i i}\right)$ dibagi varian return pasar $\left(\sigma^{2}{ }_{M}\right)$. Nilai $\sigma^{2}{ }_{M}$ telah diketahui menggunakan bantuan software Matlab yaitu 0,0001 . Tingkat suku bunga Bank Indonesia (SBI) selama periode tersebut, dalam bentuk harian sebesar 0,34\% $(r=0,0034)$. Sehingga dapat dianalisis nilai expected return model CAPM untuk setiap saham sebagai berikut: 
Tabel 2 Nilai $\beta_{i}$ dan $R_{i}$ Model CAPM.

\begin{tabular}{|c|c|c|c|c|c|c|c|}
\hline No & Kode & $\beta_{i}=\frac{\sigma_{i}}{\sigma^{2}{ }_{M}}$ & $R_{i}=r_{f}+\beta_{i}\left(r_{M}-r_{f}\right)$ & No & Kode & $\beta_{i}=\frac{\sigma_{i i}}{\sigma^{2}{ }_{M}}$ & $\boldsymbol{R}_{i}=\boldsymbol{r}_{\boldsymbol{f}}+\boldsymbol{\beta}_{i}\left(\boldsymbol{r}_{\boldsymbol{M}}-\boldsymbol{r}_{\boldsymbol{f}}\right)$ \\
\hline 1 & AKRA & 0,8630 & 0,0008 & 13 & MPPA & 0,7704 & 0,0011 \\
\hline 2 & ASII & 1,5268 & $-0,0012$ & 14 & PGAS & 0,9307 & 0,0006 \\
\hline 3 & ASRI & 1,8342 & $-0,0021$ & 15 & PTBA & 1,1577 & $-0,0001$ \\
\hline 4 & BSDE & 1,7304 & $-0,0018$ & 16 & PTPP & 1,6487 & $-0,0015$ \\
\hline 5 & CPIN & 1,3641 & $-0,0007$ & 17 & SILO & 0,0601 & 0,0032 \\
\hline 6 & ICBP & 0,8873 & 0,0007 & 18 & SMGR & 1,5505 & $-0,0012$ \\
\hline 7 & INCO & 0,8962 & 0,0007 & 19 & SMRA & 1,8099 & $-0,0020$ \\
\hline 8 & INDF & 0,8154 & 0,0010 & 20 & SSMS & 0,5117 & 0,0019 \\
\hline 9 & INTP & 1,5751 & $-0,0013$ & 21 & TLKM & 1,1847 & $-0,0001$ \\
\hline 10 & KLBF & 0,8902 & 0,0007 & 22 & UNVR & 1,0479 & 0,0003 \\
\hline 11 & LSIP & 1,6450 & $-0,0015$ & 23 & WIKA & 1,7243 & $-0,0018$ \\
\hline 12 & MNCN & 0,7667 & 0,0011 & & & & \\
\hline
\end{tabular}

Nilai beta menunjukkan ukuran kepekaan return saham terhadap perubahan pasar atau bisa juga diartikan menunjukkan ukuran risiko saham, semakin besar $\beta$ maka semakin besar pula risiko yang terkandung dalam suatu saham. Nilai $\beta>1$ yang berarti return pada saham tersebut peka terhadap segala perubahan pasar yang terjadi. Selain itu, terdapat pula nilai $\beta<1$ berarti return saham tersebut memiliki kepekaan lebih kecil dari fluktuasi pasar. Saham yang memiliki nilai $\beta<1$ diantaranya saham AKRA, ICBP, INCO, INDF, KLBF, MNCN, MPPA, PGAS, SILO dan SSMS.

Setelah diketahui nilai expected return model CAPM untuk masing-masing saham, selanjutnya akan dibentuk portofolio dengan menggunakan 5 saham yang memiliki expected return terbesar. Terpilihnya saham dengan expected return terbesar, dikarenakan Model Black Litterman akan menggunakan nilai expected return CAPM tersebut dalam membentuk portofolio optimal, juga akan dilakukan perbandingan antara kedua model tersebut. Saham-saham tersebut adalah:

Tabel 3 Saham dengan Expected Return CAPM Terbesar.

\begin{tabular}{llllll}
\hline Kode & INDF & MNCN & MPPA & SILO & SSMS \\
\hline $\boldsymbol{R}_{\boldsymbol{i}}$ & 0,0010 & 0,0011 & 0,0011 & 0,0032 & 0,0019 \\
\hline
\end{tabular}

Bobot dari masing-masing aset pembentuk portofolio dapat dihitung menggunakan rumus:

$$
c=\frac{1}{1_{p}^{T}\left(\mu-r 1_{p}\right) \Sigma^{-1}}\left(\mu-r 1_{p}\right) \Sigma^{-1}
$$

Tabel 4 Proporsi Saham Pembentuk Portofolio CAPM.

\begin{tabular}{llllll}
\hline Kode & INDF & MNCN & MPPA & SILO & SSMS \\
$\boldsymbol{R}_{\boldsymbol{i}}$ & 0,0010 & 0,0011 & 0,0011 & 0,0032 & 0,0019 \\
Proporsi & $60,91 \%$ & $14,70 \%$ & $13,83 \%$ & $-1,09 \%$ & $11,66 \%$ \\
\hline
\end{tabular}

Proporsi saham pembentuk portofolio bernilai positif dan negatif. Saham dengan proporsi terbesar adalah saham INDF dengan proporsi $60,91 \%$, sedangkan saham dengan proporsi terkecil adalah saham SILO dengan $-1,09 \%$. Dengan demikian portofolio model CAPM terbentuk dari saham-saham, diantaranya saham INDF, MNCN, MPPA, SILO dan SSMS.

Portofolio yang terbentuk menghasilkan mean return

$$
R_{m}=\sum_{i=1}^{n} W_{m} \mu_{m}=0,0011 \text {, dan resikonya } \sigma_{m}{ }^{2}=\left(W_{m}{ }^{*}\right)^{T} \Sigma W_{m}=0.0001195
$$




\section{Pembentukan Portofolio dengan Black Litterman}

Saham yang akan digunakan dalam perhitungan portofolio model Black Litterman adalah 5 saham dengan nilai expected return terbesar model CAPM. Model Black Litterman mengkombinasikan antara views investor dengan return ekuilibrium yang dicapai melalui CAPM, sehingga dapat menghasilkan return portofolio yang baru. Return ekuilibrium dari saham terpilih yang telah dicapai model CAPM adalah sebagai berikut:

Tabel 5 Return Ekuilibrium ( $\pi$ ) melalui CAPM.

\begin{tabular}{cc}
\hline Kode & $\boldsymbol{\pi}=\boldsymbol{r}_{\boldsymbol{f}}+\boldsymbol{\beta}_{\boldsymbol{i}}\left(\boldsymbol{r}_{\boldsymbol{M}}-\boldsymbol{r}_{\boldsymbol{f}}\right)$ \\
\hline INDF & 0,0010 \\
MNCN & 0,0011 \\
MPPA & 0,0011 \\
SILO & 0,0032 \\
SSMS & 0,0019 \\
\hline
\end{tabular}

Nilai return ekuilibrium sama dengan return yang telah dicapai melalui model CAPM. Return CAPM selanjutnya akan disimbolkan dengan $\pi$. ini:

Hubungan antar saham-saham pembentuk portofolio dapat ditunjukkan pada matriks korelasi bawah

Tabel 6 Korelasi Saham Pembentuk Portofolio.

\begin{tabular}{lccccc}
\hline & INDF & MNCN & MPPA & SILO & SSMS \\
\hline INDF & 1 & 0,213 & 0,110 & 0,097 & 0,202 \\
MNCN & 0,213 & 1 & 0,186 & 0,088 & 0,145 \\
MPPA & 0,110 & 0,186 & 1 & 0,115 & $-0,074$ \\
SILO & 0,097 & 0,088 & 0,115 & 1 & 0,059 \\
SSMS & 0,202 & 0,145 & $-0,074$ & 0,059 & 1 \\
\hline
\end{tabular}

Saham-saham pembentuk portofolio memiliki tingkat hubungan yang sangat lemah antar saham yakni dalam rentang nilai $0<|\rho|<0.25$, kecuali saham yang berkorelasi dengan dirinya sendiri dimana memiliki tingkat hubungan yang sempurna yaitu 1. Seluruh saham memiliki korelasi yang positif, kecuali saham SSMS dengan saham MPPA yang memiliki korelasi negatif.

Langkah berikutnya dalam model Black Litterman adalah dengan membentuk matriks varians kovarians $(\Sigma)$ dari aset yang terpilih (Tabel 5.10)

Tabel 7 Matriks Varians Kovarians Aset.

\begin{tabular}{lccccc}
\hline $1.0 \mathrm{e}-003 *$ & INDF & MNCN & MPPA & SILO & SSMS \\
\hline INDF & 0,1758 & 0,0569 & 0,0459 & 0,0100 & 0,0389 \\
MNCN & 0,0569 & 0,4510 & 0,1005 & 0,0316 & 0,0359 \\
MPPA & 0,0459 & 0,1005 & 0,5946 & 0,0435 & $-0,0447$ \\
SILO & 0,0100 & 0,0316 & 0,0435 & 0,3772 & $-0,0282$ \\
SSMS & 0,0389 & 0,0359 & $-0,0447$ & $-0,0282$ & 0,4816 \\
\hline
\end{tabular}

Dibentuknya matriks varians kovarian, yang akan dijadikan dasar dalam membantu membangun views investor terhadap masing-masing aset. Nilai views ditentukan oleh pandangan investor. Dikarenakan dalam views yang diberikan investor terhadap aset terpilih masih mengandung ketidakpastian, sehingga harus diukur melalui confidence level. Views investor dibentuk dengan menggunakan bantuan data harga saham sebelumnya sebagai berikut: 
Tabel 8 Return Saham tanggal 30 Januari 2015.

\begin{tabular}{lccc}
\hline Saham & $\left(\boldsymbol{P}_{\boldsymbol{t}}\right)$ & $\left(\boldsymbol{P}_{\boldsymbol{t}-\mathbf{1}}\right)$ & $\boldsymbol{R}_{\boldsymbol{i}}=\boldsymbol{l} \boldsymbol{1}\left(\frac{\boldsymbol{P}_{\boldsymbol{t}}}{\boldsymbol{P}_{\boldsymbol{t}-\mathbf{1}}}\right)$ \\
\hline INDF & 7550 & 7375 & 0,02345 \\
MNCN & 2860 & 2860 & 0 \\
MPPA & 3800 & 3600 & 0,054067 \\
SILO & 13400 & 13300 & 0,007491 \\
SSMS & 1650 & 1635 & 0,009132 \\
\hline
\end{tabular}

dengan

$P_{t} \quad=$ harga saham pada saat $\mathrm{t}$

$P_{t-1}=$ harga saham pada saat $\mathrm{t}-1$

$R_{i} \quad=$ return saham ke-i

Tabel 9 Return Selisih Harga Terakhir dan Sebelumnya.

\begin{tabular}{lccc}
\hline Saham & $29 / 01 / 2015$ & $30 / 01 / 2015$ & Selisih \\
\hline INDF & $-0,00338$ & 0,02345 & 0,026836 \\
MNCN & 0,00175 & 0 & 0,00175 \\
MPPA & 0,011173 & 0,054067 & 0,042894 \\
SILO & 0 & 0,007491 & 0,007491 \\
SSMS & $-0,02118$ & 0,009132 & 0,030313 \\
\hline
\end{tabular}

Hasil selisih return di atas dapat digunakan untuk membentuk views absolute maupun views relative. Views absolute akan dibentuk pada saham INDF, MNCN dan MPPA. Sedangkan views relative dibentuk pada saham SILO dan SSMS dengan perhitungan:

Views Relative $=$ Selisih Return SSMS - Selisih Return SILO

$$
\begin{aligned}
& =0,030313-0,007491 \\
& =0,022822
\end{aligned}
$$

Sehingga views absolute dan views relative dapat terbentuk sebagai berikut:

Views 1 : saya memprediksi saham INDF akan memberikan return $3 \%$

Views 2 : saya memprediksi saham $\mathrm{MNCN}$ akan memberikan return $0,2 \%$

Views 3 : saya memprediksi saham MPPA akan memberikan return $4 \%$

Views 4 : saya memprediksikan saham SSMS akan memberikan return $2 \%$ melebihi saham SILO

Views 1, 2 dan 3 merupakan views absolute dan views 4 merupakan views relative.

Views investor di atas dapat dinyatakan dalam matriks $Q$ :

$$
Q=\left[\begin{array}{c}
0.03 \\
0.002 \\
0.04 \\
0.02
\end{array}\right]
$$

Suatu matriks konektor akan dibentuk berdasarkan views yang telah diberikan oleh investor. Matriks tersebut (link matriks) juga akan dimasukkan ke dalam formula Black Litterman.

$$
P=\left[\begin{array}{ccccc}
1 & 0 & 0 & 0 & 0 \\
0 & 1 & 0 & 0 & 0 \\
0 & 0 & 1 & 0 & 0 \\
0 & 0 & 0 & -1 & 1
\end{array}\right]
$$


Baris dalam matriks $P$ menjelaskan tentang views dan kolom menjelaskan tentang aset. Saham yang akan memberikan return yang lebih dari saham yang lain (outperforming) akan dinyatakan dalam nilai positif. Sedangkan saham yang underperforming akan diberikan nilai negatif. Sehingga, jumlah dari bobot views absolute yang diberikan dalam matriks $P$ adalah 1 dan views relative berjumlah 0 .

Varians dari views masing-masing yang tergabung dalam portofolio dirumuskan $p_{k} \Sigma p_{k^{\prime}}$, dimana $p_{k}$ adalah baris pertama dalam matriks $P$. Varians dari views ini akan digunakan untuk menghitung varians dari error $(\omega)$ yang disusun dalam element diagonal $\Omega$.

Table 10 Varians dari Views Portofolio.

\begin{tabular}{ccc}
\hline Views & Rumus & Varians \\
\hline 1 & $p_{1} \Sigma p^{\prime}{ }_{1}$ & $0,0002 \%$ \\
2 & $p_{2} \Sigma p^{\prime}{ }_{2}$ & $0,0005 \%$ \\
3 & $p_{3} \Sigma p^{\prime}{ }_{3}$ & $0,0006 \%$ \\
4 & $p_{4} \Sigma p^{\prime}{ }_{4}$ & $0,0009 \%$ \\
\hline
\end{tabular}

Keyakinan views investor dapat dinyatakan dalam matriks kovarian dari error $(\Omega)$ dalam rumus:

$$
\Omega=\left[\begin{array}{cccc}
\left(p_{1} \sum p_{1}^{\prime}\right) * \alpha & 0 & 0 & 0 \\
0 & \left(p_{2} \sum p^{\prime}{ }_{2}\right) * \alpha & 0 & 0 \\
0 & 0 & \left(p_{3} \sum p^{\prime}{ }_{3}\right) * \alpha & 0 \\
0 & 0 & 0 & \left(p_{4} \sum p^{\prime}{ }_{4}\right) * \alpha
\end{array}\right]
$$

Subtitusikan varians dari views dan variabel $\alpha$ diperoleh:

$$
\Omega=\left[\begin{array}{cccc}
0,0003 & 0 & 0 & 0 \\
0 & 0,0002 & 0 & 0 \\
0 & 0 & 0,0014 & 0 \\
0 & 0 & 0 & 0,0005
\end{array}\right]
$$

Kombinasi return ekuilibrium dengan views investor menghasilkan return kombinasi yang baru sebagai berikut:

$$
\mu_{b}=\pi+\left(\tau \Sigma P^{\prime}\right)\left(\Omega+P^{\prime} \tau \Sigma P\right)^{-1}(Q-P)
$$

Variabel $\tau$ adalah angka yang diberikan investor, Blamont dan Firoozye (2003) mengasumsikan $\tau=$ 1/jumlah observasi, yaitu $\tau=1 / 282=0,0035$.

Tabel 11 Return Kombinasi yang Baru $\left(\mu_{b}\right)$.

\begin{tabular}{lc}
\hline Saham & Kombinasi Return $\left(\boldsymbol{\mu}_{\boldsymbol{b}}\right)$ \\
\hline INDF & 0,0010 \\
MNCN & 0,0011 \\
MPPA & 0,0011 \\
SILO & 0,0032 \\
SSMS & 0,0019 \\
\hline
\end{tabular}

Bobot dari masing-masing aset pembentuk portofolio dapat dihitung menggunakan rumus:

$$
W_{b}=W_{m}+P^{\prime}\left(\frac{\Omega}{\tau}+P^{\prime} \Sigma P\right)^{-1}\left(\frac{Q}{\delta}-P \Sigma W_{m}\right)
$$


Tabel 12 Proporsi Saham Pembentuk Portofolio BL.

\begin{tabular}{lcc}
\hline Saham & Kombinasi Return $\left(\boldsymbol{\mu}_{\boldsymbol{b}}\right)$ & Bobot BL $\left(\boldsymbol{W}_{\boldsymbol{b}}\right)$ \\
\hline INDF & 0,0010 & $61,01 \%$ \\
MNCN & 0,0011 & $13,99 \%$ \\
MPPA & 0,0011 & $15,71 \%$ \\
SILO & 0,0032 & $-5,94 \%$ \\
SSMS & 0,0019 & $15,23 \%$ \\
\hline
\end{tabular}

Saham dengan proporsi terbesar adalah saham INDF dengan proporsi 61,01\%, sedangkan saham dengan proporsi terkecil adalah saham SILO dengan proporsi $-5,94 \%$. Dari proporsi ini dapat dihitung nilai untuk mean return dan risiko dari portofolio model Black Litterman. Portofolio dengan komponen pembentuk saham-saham di atas menghasilkan nilai mean return

$$
R_{b}=\sum_{i=1}^{n} W_{b} \mu_{b}=0,0012, \text { dan resikonya } \sigma_{b}{ }^{2}=\left(W_{b}{ }^{*}\right)^{T} \Sigma W_{b}=0.00012946
$$

Proporsi saham yang negatif dalam portofolio di atas dapat menyebabkan kerugian investasi, sehingga harus dibentuk portofolio baru dengan mengeluarkan saham proporsi negatif yaitu saham SILO. Bobot dari masing-masing aset pembentuk portofolio adalah:

Tabel 13 Proporsi Saham Pembentuk Portofolio.

\begin{tabular}{lcc}
\hline Saham & Kombinasi Return $\left(\boldsymbol{\mu}_{\boldsymbol{b}}\right)$ & Bobot BL $\left(\boldsymbol{W}_{\boldsymbol{b}}\right)$ \\
\hline INDF & 0,0010 & $54,44 \%$ \\
MNCN & 0,0012 & $11,69 \%$ \\
MPPA & 0,0012 & $13,17 \%$ \\
SSMS & 0,0021 & $20,70 \%$ \\
\hline
\end{tabular}

Saham dengan proporsi terbesar adalah saham INDF dengan proporsi 54,44\%, sedangkan saham dengan proporsi terkecil adalah saham MNCN dengan proporsi $11,69 \%$. Dari proporsi ini dapat dihitung nilai untuk mean return dan risiko dari portofolio model Black Litterman. Portofolio dengan komponen pembentuk saham-saham di atas menghasilkan nilai mean return 0,0013 dan risikonya 0,00011420 .

\section{Kesimpulan}

Portofolio optimal model Black Litterman terbentuk dari saham INDF, MNCN, MPPA dan SSMS. Dari saham pembentuk portofolio tersebut, saham dengan proporsi terbesar adalah INDF yaitu sebesar $54,44 \%$ dengan expected return 0,0010 dan proporsi terkecil adalah MNCN yaitu 11,69\% dengan expected return 0,0012. Portofolio optimal dengan ketidakyakinan views menghasilkan mean return 0,0013 dan risiko 0,00011420.

Portofolio model Black Litterman memiliki risiko yang lebih kecil yakni 0,00011420 dibandingkan model yang lain, dalam hal ini adalah model CAPM yang memiliki risiko sebesar 0,00011756. Model $\mathrm{BL}$ ini juga dapat memberikan prediksi return yang lebih besar dibanding CAPM.

\section{Referensi}

[1] Anton, H. 2000. Dasar-dasar Aljabar Linear. Jakarta: Erlangga.

[2] Astuti, R, dkk. 2013. Analisis Pengaruh Tingkat Suku Bunga (SBI), Nilai Tukar (Kurs) Rupiah dan Indeks Bursa International terhadap IHSG (Studi Kasus pada IHSG di BEI periode 2008 2012). Diponegoro Journal of Social and Politic of Science. Hal 1-8.

[3] Black, Fischer; Litterman, Robert, 1992, Global Portfolio Optimization, Financial Analysts Journal ;Sep/Oct 1992 ;48

[4] Da, Zhi. 2005. Teaching Note on Black-Litterman Model. Dow Jones \& Company, Inc.

[5] Fahmi, I, dkk. 2009. Teori Portofolio dan Analisis Investasi: Teori dan Soal Jawab. Bandung: Alfa Beta.

[6] Gudono. 2014. Analisis Data Multivariat. Yogyakarta: BPFE. 
[7] Halim, A. 2005. Analisis Investasi. Jakarta: Salemba Empat.

[8] Hardler, W dan Leopord, S. 2003. Applied Multivariate Statistical Analysis. Berlin: MDTech.Inc.

[9] He, G. and R. Litterman. 1999. The Intuition Behind Black-Litterman Model Portfolios, Investment Management Research, Goldman, Sachs \& Company.

[10] Imron, A. K. 2013. Analisis Portofolio Optimal Menggunakan Capital Asset Pricing Model (CAPM) pada Saham Syariah Jakarta Islamic Index (JII). Skripsi. Yogyakarta: Saintek UIN Sunan Kalijaga.

[11] Jogiyanto. 2000. Teori Portofolio dan Analisis Investasi Edisi Ke-Dua. Yogyakarta: BPFE.

[12] Jogiyanto. 2003. Teori Portofolio dan Analisis Investasi Edisi Ke-Tiga. Yogyakarta: BPFE.

[13] Mankert, C. 2006. The Black-Litterman Model. Stockholm: Royal Institute of Technology.

[14] Mayasari, T. 2008. Preferensi Investor dalam Pembentukan Portofolio Optimal dengan Model Black Litterman. Skripsi. Yogyakarta: FMIPA UGM

[15] Qudratullah, F.M, dkk. 2012. Statistika. Yogyakarta: SUKA-Press UIN Sunan Kalijaga.

[16] Rencher, A. 2002. Methods of Mltivariate Analysis. John Wiley \& Sons, Inc.

[17] Silva, A, dkk. 2009. The Black-Litterman Model for Active Portfolio Management. Neuberger Berman: NB Alternative Fund Management LLC.

[18] Subekti, R. 2008. Aplikasi Model Black-Litterman dengan Pendekatan Bayes. Prosiding Seminar Nasional. Yogyakarta: FMIPA UNY.

[19] Subekti, R. 2009. Keunikan Model Black Litterman dalam Pembentukan Portofolio. Prosiding Seminar Nasional. Yogyakarta: FMIPA UNY.

[20] Subekti, R. 2013. Aplikasi Pembentukan Portofolio Saham LQ-45 Menggunakan Model Black Litterman dengan Estimasi Theil Mixed. Prosiding Seminar Nasional. Yogyakarta: FMIPA UNY.

[21] Sudjana. 1996. Metoda Statistika. Bandung: TARSITO.

[22] Suhartono, 2009. Portofolio Investasi dan Bursa Efek: Pendekatan Teori dan Praktik. Yogyakarta; UPP STIM YKPN.

[23] Sugiarto. 2014. Statistika Ekonomi dan Bisnis. Banten: Universitas Terbuka.

[24] Suryomukti, W. 2011. Supercerdas Investasi Syariah. Jakarta: Qultum Media.

[25] Thomas M. Idzorek, 2005, A Step-By-Step Guide To Black Litterman Model, Incorporating user-specified confidence levels, Chicago, Illinois.

[26] Walpole, E.R. 1992. Pengantar Statistika. Jakarta: PT Gramedia Pustaka Utama.

[27] Walters, J. 2009. The Black-Litterman Model In Detail. rev.ed.

[28] Widayat, Wahyu. 2013. Matematika Ekonomi dan Bisnis. Banten: Universitas Terbuka.

[29] Winarno, W. 2009. Analisis Ekonometrika dan Statistika dengan Eviews. Yogyakarta; UPP STIM YKPN. 